УДК 339.727 .22

A. Alikbanov,

$\mathrm{PbD}$ candidate at Finance and Financial Institutions Faculty,

Azerbaijan State University of Economics

ORCID iD: 0000-0001-5165-2963

DOI: $10.32702 / 2306-6814.2019 .8 .83$

\title{
ESTIMATING FISCAL SUSTAINABILITY HYPOTHESIS AND ANALYZING RELATIONSHIP BETWEEN DEBT AND FDI INFLOWS
}

\author{
А. Е. Алиханов, \\ диссертант, Факультет Финансов и Финансовых Учреждений, \\ Азербайджанский Государственный Экономический Университет
}

\section{ОЦЕНКА ГИПОТЕЗЫ ФИНАНСОВОЙ УСТОЙЧИВОСТИ И АНААИЗ ВЗАИМОСВЯЗИ МЕЖАУ ПРИТОКОМ ЗААОАЖЕННОСТИ И ПРИТОКОМ ПИИ}

The aim of paper is to analyze fiscal sustainability and to test fiscal sustainability hypothesis. It should be mentioned that fiscal sustainability is considered one of the key indication for central governments. Firstly, individual fiscal discipline is pivotal proxy for the establishment of common monetary policy. Second, debt accumulation associated with consequent budget deficit may yield to increase in long term interest rates that can cause negative affects to financial markets. Third, member states will be able to keep criteria's of aforementioned Maastricht convergence criteria (Eduard, Tomash, and Stefan, 2011 ). To test the hypothesis some selected Euro zone countries, including United Kingdom and Azerbaijan were selected. In empirical part of the article author examines fiscal sustainability hypothesis of selected countries. Countries selected in Eurozone are mainly those that possessed vulnerabilities during European debt crises. As such, sustainability hypothesis is examined by applying Panel Unit Root tests for debt-toGDP ratio from 1995 to 2016 period. In the methodology, theoretical background of the ratio is explained. The empirical test evidence using root test demonstrated us incapability of rejection hypothesis in levels. Further paper also analyses the relationship between government debt-to-GDP ratio and Foreign Direct Investments using correlation analysis for countries. FDI is one of the main economic indicator that supports the growth of economies of the countries via contribution to the transfer of new technologies and resources, to the realization of reforms and setting up of financial institutions and to stabilize fiscal sustainable in different ways.

Author starts article starts briefly description about crises that triggered fiscal sustainability issues. The discussion also includes analyses of relationship between FDI and total debt of selected countries. Further, in the analyses of study author discusses theoretical part, which then followed by several literatures reviews on growth and government debt relations. Article provides data and methodology aiming to of the aim of the researched article. Finally, in summary for of the basis of research materials author provides findings and summarizes concluding remarks.

Целью работы является обсуждение и анализ устойчивости бюджета и проверка гипотезы устойчивости бюджета. Следует отметить, что финансовая устойчивость считается одним из ключевых показателей для центральных правительств. Во-первых, индивидуальная фискальная дисциплина является ключевым фактором для формирования общей денежно-кредитной политики. Вовторых, накопление задолженности, связанное с последующим дефицитом бюджета, может привести к увеличению долгосрочных процентных ставок, что может оказать негативное влияние на финансовые рынки. В-третьих, государства-члены смогут сохранить критерии вышеупомянутых критериев сходимости в Маастрихте (Eduard, Tomash, и Stefan, 2011). Для проверки гипотезы были выбраны некоторые страны Еврозоны, в том числе Великобритания и Азербайджан. В эмпирической части статьи автор рассматривает гипотезу устойчивости бюджета выбранных стран. Страны, выбранные в еврозоне, - это, в основном, страны, которые были уязвимы во время европейских долговых кризисов. Таким образом, гипотеза об устойчивости рассматривается путем применения корневых тестов Panel Unit root. Для оценки показателя соотношения долга а ВВП с 1995 по 2016 год. В методологии объясняется теоретический фон соотношения. Эмпирические тесты с использованием корневого теста продемонстрировали нам неспособность гипотезы отклонения в уровнях. В дальнейшем документе также анализируется взаимосвязь между соотношением государственного долга к ВВП и прямыми иностранными инвестициями с использованием корреляционного анализа для стран. ПИИ является одним из основных экономических показателей, который 
поддерживает рост экономики стран за счет вклада в передачу новых технологий и ресурсов, реализацию реформ и создание финансовых институтов, а также стабилизацию фискальной устойчивости различными способами.

Автор начинает статью с краткого описания кризисов, которые вызвали проблемы устойчивости бюджета. Обсуждение также включает анализ взаимосвязи между ПИИ и общей задолженностью отдельных стран. Далее в анализах исследования автор обсуждает теоретическую часть, за которой следуют несколько литературных обзоров о росте и связью с государственным долгом. В статье приведены данные и методология, используемые в описанной работе. В заключительной части резюме на основе материалов исследования автор делает выводы и резюмирует заключительные замечания.

Метою статтіє аналіз фіскальної стійкості та перевірка гіпотези фіскальної стійкості. Слід зазначити, що фіскальна стійкість вважається одним з ключових показників для центральних органів влади. По-перше, індивідуальна фіскальна дисципліна є ключовим фактором для встановлення спільної монетарної політики. По-друге, накопичення боргу, пов'язане з таким дефіцитом бюджету, може призвести до збільшення довгострокових процентних ставок, що може спричинити негативний вплив на фінансові ринки. По-третє, держави-члени зможуть дотримуватись критеріїв вищезгаданих критеріїв конвергенції в Маастрихті (Едуард, Томаш, Стефан, 2011). Для перевірки гіпотези були відібрані окремі країни Єврозони, включаючи Великобританію та Азербайджан. У емпіричній частині статті автор розглядає гіпотезу фіскальної стійкості окремих країн. Країни, обрані в Єврозоні, це в основному ті країни, які були вразливі під час європейських боргових криз. Таким чином, гіпотеза стійкості розглядається шляхом застосування групових тестів Panel Unit Root для оцінки показника співвідношення боргу до ВВП у період з 1995 по 2016 рік. У методології пояснюється теоретична основа співвідношення. Докази емпіричного тесту з використанням кореневого тесту показали нам нездатність гіпотези відхилення в рівнях. Подальша робота також аналізує взаємозв'язок між співвідношенням державного боргу до ВВП та прямими іноземними інвестиціями з використанням кореляційного аналізу для країн. ПІІ є одним з основних економічних показників, який підтримуює зростання економік країн за рахунок внеску у передачу нових технологій і ресурсів, для здійснення реформ, створення фінансових інститутів і стабілізації фіскальної стійкості різними способами.

Автор починає статтю з короткого опису криз, які викликали проблеми фіскальної стійкості. Обговорення включає також аналіз взаємозв'язку між ПІІ та загальним боргом окремих країн. Далі в аналізах дослідження автор обговорює теоретичну частину, яка потім супроводжується кількома літературними оглядами про зростання і державні боргові відносини. У статті наведено дані та методологія, які використовуються у роботі. Узаключній частині на основі матеріалів дослідження автор дає висновки і узагальнює заключні зауваження.

Key words: financial sustainability, foreign direct investment, unit root.

Ключеъые слова: фонансовая устойчиВость, прямые иностранные инъестиции, единичный корень.

Ключові слоВа: фонансова стійкість, прямі іноземні інВестиції, одиничний корінь.

\section{INTRODUCTION AND PROBLEM}

\section{STATEMENT}

The recent European debt crises in 2010-2011 years yield to reveal the vulnerabilities of fiscal sustainability of some Euro Zone countries. As such, the fiscal sustainability has been considered one of the central macroeconomic tasks of the European Union countries. European Union's Maastricht Treaty indicates that the member states pledged to limit their deficit spending 3 percent of GDP at most, and should keep debt levels at 60 percent of GDP. The Maastricht criteria was mainly motivated by Germany to ensure that the qualifying members had a strong fiscal and monetary background. (Pilbeam, 2006). Moreover, after the crises countries began to improve fiscal sustainability of the economies through various actions, including promoting foreign investors to invest. In primarily to what attract foreign investments to country and expand size of economies. These are also achieved through foreign direct investments (FDI).

During 2010 and 2011 years, euro zone nations faced their own type of fiscal distress because of heavy borrowing practices (Greece, Portugal and Italy), property bubbles (Ireland and Spain). The accessibility of easy credit led to an overreliance on external credit sources to fund domestic debt (Sandoval et al., 2011). Identifying the trigger of the crisis is a difficult task, but a relevant starting point would be that of the case of Greece. Greece was living beyond its means since even before it became part of the Euro zone in 2001. After adopting the euro, the Greek government borrowed heavily and public spending soared. Combined with a failure to implement financial reforms, this left Greece badly exposed when the global financial crisis struck. It became evident that Greece was 


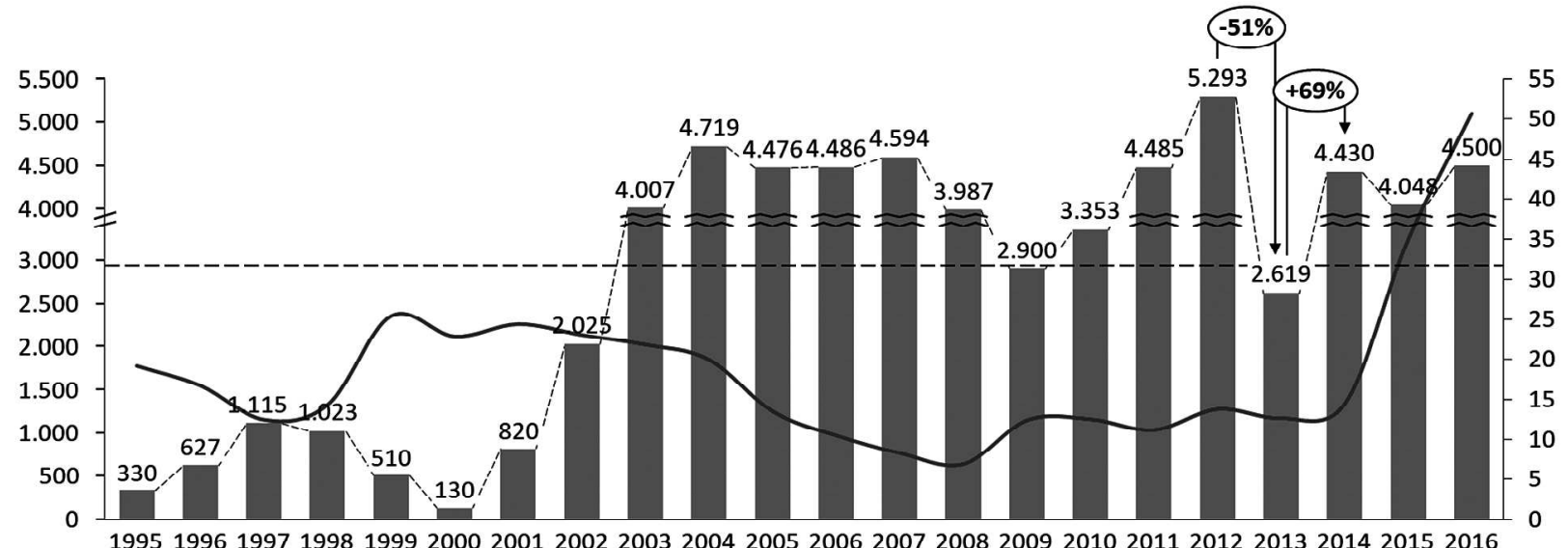

Debt-to-GDP ratio

FDI Azerbaijan

Figure 1. FDI and Debt-to-GDP ratio of Azerbaijan from 1995 to 2016 years

Source: World Bank development Indicators, 2016.

in need of financial aid. Thus, in May 2010 Greece was provided with $€ 110$ bn of bailout loans by the IMF and in July 2011 an additional $€ 109$ bn of bailout loans were earmarked to Greece. However, this still seems to be insufficient for the country to get out of the crisis; by the middle of November 2011, Greece's debt amounted to more than $€ 340$ bn (BBC News, 2011). Furthermore, the euro zone's single currency makes it easy to shift money across borders from risky economies to safer ones.

Because financial institutions in most European countries holding Greek bonds, they were susceptible to downgrade risks by rating agencies. (New York Times, 2011) To give an example, Moody's downgraded two large French banks, Credit Agricole and Societe Generale, due to the financial institutions' exposure to Greek bonds and debts of some other risky members of the Eurozone. (CNN, 2011) Secondly, the risk of contagion can be observed through increasing borrowing costs. For example, the crisis within the Eurozone caused by Greece, led to significantly higher borrowing costs for Italy, peaking at almost 8 percent in November 2011. (Reuters, 2011). Even though Greece marked the onset of the crisis, several other countries seemed to suffer from sustainability of debt. We can notice that Debt over GDP significantly increased, especially in the case of Greece and Italy (Figure 1).

Despite the fact that the EU countries had responsibilities to maintain the obligations within the Maastricht Treaty, i.e. keep government debt stable and pledge deficit levels, during the $2000-2010$ years last decade public debt of Greece, Italy, Portugal mainly have increased significantly. The same negative trend in debt/GDP ratio can be said about Ireland and Portugal, which are above the average EU level of $80.1 \%$ in 2010 (World Bank, 2018). As per the figure 1, Azerbaijan debt has been more stable compared to economies with sovereign debt issues. During 2010-2011 years, most EU countries GDP growth rate was also suffered, however after then they restored position. Ireland made a significant improvement. However, Italy and Greece Italy are still facing negative economic performance (World Bank, 20017).

Analysis of researches: theoretical background

The major indicator for empirical testing is the notion of fiscal sustainability in terms of Debt-to-GDP Ratio. The theoretical motive for this macroeconomic indicator starts with government budget constraint. According to previous theoretical papers on fiscal sustainability government budget can be expressed as following (Wilcox, 1989):

$$
G_{t}+\left(1+r_{t}\right) D_{t-1}=R_{t}+D_{t}
$$

Table 1. Government debt as a percentage of GDP (Debt-to GDP Ratio)

\begin{tabular}{|l|l|l|l|l|l|l|l|}
\hline Years & BELGIUM & GREECE & IRELAND & ITALY & PORTUGAL & UK & AZE \\
\hline 1995 & 116.0 & 100.8 & 77.5 & 115.2 & 56.2 & 44.6 & 19.2 \\
\hline 1996 & 113.2 & 103.2 & 69.6 & 114.8 & 57.4 & 44.5 & 16.7 \\
\hline 1997 & 110.4 & 99.9 & 61.3 & 112.0 & 53.4 & 42.5 & 12.5 \\
\hline 1998 & 106.0 & 97.3 & 51.2 & 108.9 & 50.9 & 40.6 & 14.3 \\
\hline 1999 & 103.1 & 96.5 & 48.4 & 107.0 & 51.0 & 39.4 & 25.4 \\
\hline 2000 & 98.2 & 98.5 & 37.9 & 102.0 & 49.8 & 36.6 & 22.8 \\
\hline 2001 & 97.6 & 95.8 & 34.8 & 101.4 & 52.3 & 34.0 & 24.4 \\
\hline 2002 & 94.7 & 101.6 & 32.3 & 98.7 & 54.8 & 34.0 & 23.0 \\
\hline 2003 & 88.9 & 99.4 & 31.5 & 96.2 & 57.2 & 35.1 & 21.8 \\
\hline 2004 & 84.5 & 104.4 & 29.8 & 95.6 & 60.4 & 37.9 & 20.0 \\
\hline 2005 & 83.5 & 108.1 & 28.9 & 96.9 & 65.2 & 39.0 & 13.5 \\
\hline 2006 & 80.5 & 103.8 & 26.1 & 96.6 & 67.0 & 39.8 & 10.5 \\
\hline 2007 & 77.0 & 102.9 & 26.4 & 93.7 & 66.2 & 40.9 & 8.3 \\
\hline 2008 & 82.2 & 108.3 & 45.0 & 96.6 & 69.6 & 49.0 & 6.9 \\
\hline 2009 & 85.9 & 125.7 & 64.5 & 105.7 & 81.0 & 63.2 & 12.4 \\
\hline 2010 & 85.3 & 150.5 & 89.7 & 108.7 & 93.6 & 74.6 & 12.5 \\
\hline 2011 & 87.7 & 177.7 & 114.2 & 110.0 & 109.1 & 80.3 & 11.2 \\
\hline 2012 & 88.7 & 159.8 & 123.5 & 116.9 & 125.5 & 83.6 & 13.8 \\
\hline 2013 & 89.7 & 178.2 & 123.3 & 123.0 & 128.8 & 84.7 & 12.6 \\
\hline 2014 & 90.1 & 182.5 & 108.8 & 126.4 & 131.2 & 86.4 & 14.4 \\
\hline 2015 & 89.6 & 182.6 & 80.3 & 126.4 & 129.6 & 87.2 & 35.0 \\
\hline 2016 & 89.8 & 186.0 & 75.9 & 127.3 & 131.4 & 87.1 & 50.7 \\
\hline
\end{tabular}

Source: World Bank Indicators, 2016. 
Table 2. Statistical properties and normality test (Debt to GDP ratios)

\begin{tabular}{|l|l|l|l|l|l|l|c|}
\hline & AZERBAIJAN & BELGIUM & GREECE & IRELAND & ITALY & PORTUGAL & UK \\
\hline Mean & 18.27 & 92.84 & 125.6 & 62.76 & 108.1 & 79.16 & 54.78 \\
\hline Median & 14.34 & 89.67 & 104.1 & 56.26 & 107.8 & 62.15 & 43.47 \\
\hline Maximum & 50.71 & 115.9 & 186.0 & 123.4 & 127.2 & 131.3 & 87.23 \\
\hline Minimum & 6.90 & 76.95 & 95.75 & 26.07 & 93.70 & 48.84 & 34.04 \\
\hline Std. Dev. & 9.82 & 10.84 & 35.02 & 32.70 & 10.95 & 31.29 & 21.03 \\
\hline Skewness & 1.81 & 0.773 & 0.816 & 0.601 & 0.431 & 0.786 & 0.619 \\
\hline Kurtosis & 6.57 & 2.353 & 1.873 & 2.104 & 1.949 & 1.926 & 1.597 \\
\hline Jarque-Bera & 23.74 & 2.353 & 3.609 & 2.061 & 1.607 & 3.327 & 3.210 \\
\hline Probability & 0.979 & 0.308 & 0.164 & 0.356 & 0.447 & 0.189 & 0.201 \\
\hline Obs. & 22 & 22 & 22 & 22 & 22 & 22 & 22 \\
\hline
\end{tabular}

Source: World Bank Development Indicators, 2016.

Where $\mathrm{G}$ is denoted as Government expenditure, $\mathrm{R}$ is government Revenues, $D$ is government debt, and $r$ is interest rate on debt. Furthermore, the theory indicates that by making few rearrangements we can notice that if government revenue stays constant, the increase in budget deficit must be financed by increase in debt. The proxy for stationarity testing is if the debt $\left(D_{t+s}\right)$ in subsequent periods which stays stationary, then this stationary debt indicates slower then exponential growth. According Bohn (2007) stationarity testing suing Debt-to GDP ratios can be reviewed as one most appropriate methodology for fiscal sustainability. The fiscal sustainability indicates governments' ability to serve their debts. Since, the Debt to GDP ratio has been considered powerful indicator for fiscal sustainability, and thus sample debt-to-GDP ratio has been examined in paper. Tt is worth to note that Debtto-GDP ratio is just one corner of the fiscal sustainability approach. So, all the variables in the first equation can be expressed as the percentage of GDP and where the growth rate is expressed in $\mathrm{g}$ (B. Eduard, T. Vyrost \& S. Lyocsa, 2011).

$$
\frac{G_{t}}{G D P_{t}}+\frac{\left(1+r_{t}\right) D_{t-1}}{\left(1+g_{t}\right) G D P_{t-1}}=\frac{R_{t}}{G D P_{t}}+\frac{D_{t}}{G D P_{t}} \text { (2). }
$$

And it has been assumed that is stationary and $g$ is constant PVBC can be specified as following:

$$
\begin{aligned}
& \delta_{t-1}=\sum_{s=0}^{\infty}\left(\frac{1+g}{1+r}\right)^{s+1}\left(\rho_{t+s}-\varepsilon_{t+s}\right)+ \\
& +\lim _{s \rightarrow \infty} \delta_{t+s}\left(\frac{1+g}{1+g}\right)^{s+1}
\end{aligned}
$$

and $\delta_{t}=D_{t} / G D P_{t} ; \varepsilon_{t}=\left[G_{t}+\left(r_{t}-r\right) D_{t-1}\right] / G D P_{t}$ and $\rho_{t}=R_{t} / G D P_{t}$.

According to these expressions, whenever, the last term in equation three is zero $(r>g)$, then we get the sustainable fiscal policy and growth public debt will keep stable. According to recent empirical research, if the future inflow of surpluses, as the percentage of GDP, ties the

Table 3. Panel Unit root tests results

\begin{tabular}{|l|l|l|l|l|}
\hline & \multicolumn{2}{|c|}{ Level } & \multicolumn{2}{c|}{ First difference } \\
\hline \multicolumn{1}{|c|}{ Method } & \multicolumn{1}{|c|}{ Statistic } & P-value* & Statistic & P-valuee** \\
\hline Levin, Lin \& Chu t* & -0.40705 & 0.342 & -3.25982 & 0.0006 \\
\hline Breitung t-stat & 5.95176 & 1.0000 & -4.16295 & 0.0000 \\
\hline IPS W-stat & 3.66985 & 0.9999 & -4.93521 & 0.0000 \\
\hline ADF - Fisher Chi-square & 1.91033 & 0.9999 & 48.1747 & 0.0000 \\
\hline PP - Fisher Chi-square & 3.32467 & 0.9983 & 21.6619 & 0.0858 \\
\hline Hadri Z-stat & 5.04851 & 0.0000 & 3.07856 & 0.0010 \\
\hline
\end{tabular}

government debt, the result
(Afonso - Rault, 2010).

Regarding testing methodology, it should be noted that one of the primary ways to examine fiscal sustainability is by testing government debt for stationarity. The several empirical results provide diverse results. Afonso - Rault (2010) found that first difference of stock of government for EU-15 to be stationary from period 1970-2006, in panel LM unit root test. Moreover, they also concluded that for fiscal sustainability stationary is sufficient but it does not necessarily mean necessary condition. The Piergallini and Postigliola (2011) tested using the same approach for Italy from 1861-2009 years and they could not reject the stationarity of debt-to-GDP. According to their results Italy does not seem fiscal sustainability over that long period. However, their results indicate that Debt-to-GDP ratio appeared to be mean reverting.

Furthermore, Santos and Silvestre's (2000) test was built by using the same approach for 13 EU Member states during 1970 - 1997 years. They found out existence of our stationarity only for Germany and United Kingdom.

However, Polito et al. (2010) argue that fiscal sustainability based on the value budget constraint (PVBC) approach has somelimitations. They tested debt-GDP ratio with the expected present value of future primary deficits/surpluses through forecasts from VAR model estimating the sample data from 1970-2011 period for US and EU countries.

Purpose of paper and Methodology

The purpose of the paper is two fold. Firstly we aim to analyze fiscal sustainability and test it test this statement it in some selected Euro zone countries, including United Kingdom and Azerbaijan. Secondly, we investigate to what extent fiscal sustainability and foreign direct investments are interrelated. In this part we also discuss the trend analyses of the relationship primarily for Azerbaijan.

Paper uses the sample data for following selected EU member countries such as, Belgium, Ireland, Greece, Portugal, Italy and United Kingdom. Debt-to-GDP has been used for fiscal Sustainability by panel Unit Root Test. Moreover, sample dates, government debt as an explanatory and GDP growth as a dependent variable are tested by running simple OLS test. Yearly data is obtained from World Bank statistics Descriptive summary properties of series for fiscal sustainability is in Table 2. The Jarque Bera test probabilities reflect that the null hypothesis of normal distribution at $5 \%$ significance level is rejected for all countries.

Furthermore, in paper I used the available unit root tests available in E-views sof tware program, or namely, Augmented Dickey Fuller (ADF), Phillips-Perron (PP), 
ЕКОНОМІЧНА НАУКА

and Phillips, Schmidt, and Shin (PSS). Levin, Lin \& Chu, Breitung t-stat, Hadri Z-stat. From econometric theory indicates that if any data possess unit root, can eliminated from this non-stationary features for econometric testing purposes. Im, Pesaran and Shine (2002) shows how the panel unit root should be constructed when the similar number of times series are tested in panel data. In addition, econometric literature includes different unit root tests where we will use several of them. However, some of them require different specification.

Results and empirical summary of article

First, I tested fiscal sustainability by applying Panel Unit Root tests in E views software. All the methods we used include Augmented Dickey Fuller (ADF), Phillips Perron (PP), and Dickey Fuller (DF) ${ }^{1}$.

$\mathrm{H}_{0}: \varphi=1$

$\mathrm{H}_{0}: \varphi<1$.

They have the null hypothesis of unit roots, (all-time series in panel have a unit root). According to test results in $E$ views, the $p$-value of those tested data is more than 0.05 and the absolute t-statistics is less than the critical value. Therefore, we cannot reject the null hypothesis at $5 \%$ level. The test results indicate that null of none of the cases can be rejected ${ }^{2}$. According to panel unit root test results, we can see that sample Debt-to-GDP ratio for all the selected countries are non-stationary in levels. Table 3 summarize test results.

Thus, standard results in panel unit root provided nonstationary debt to GDP ratios. As we discussed in methodology part, by examining in first difference level in sof tware we are able to reject the null hypothesis, where transformation makes data to be stationary and thus enable us to reject the null in favor of stationarity in debtto-GDP ratio. More precisely, in the first different level, tested results indicate the rejection of null hypothesis. We can briefly conclude here that, sustainability of government debt in PVBC context can be explained partly in our panel unit root tests. Notwithstanding the fact that obtained results are not inspiring, however, the notion is to test the sustainability of debt-to-GDP ratios which is some piece of the fiscal sustainability.

Moreover, in this part of the paper, we provide trend of foreign direct investment in Azerbaijan and debt-toGDP ratio over 22 years. The average FDI over these years were amounted 2.9 billion dollar. Whilst, average FDI during 2003-2016 years was 4.1 billion dollar. Significant amount of FDI increase about $69 \%$ took place during 2014 year.

In addition, we provide, cross correlation between FDI and DEBT to GDP ratio amongst the countries estimated in our model. The pattern of relationship with FDI inflow and debt as a percentage of GDP are negative in Azerbaijan, Italy, Belgium and United Kingdom. Whilst, it has been negative in Greece and Ireland.

The correlation analyses reveal that in some countries, there is positive relationship with FDI, however, mostly the negative correlation is existed. For example, correlation coefficients are -0.07 and -0.34 for Azerbaijan and Italy respectively. Aimed with this correlation,

\footnotetext{
${ }^{1} \mathrm{E}$ views User Guide II pp. $100-101$.

2 Hadri test has a null hypothesis of no unit root in any of the series in the panel.
}

Table 4. Correlation coefficient between DEBT to GDP ratio and FDI of each countries

\begin{tabular}{|l|c|c|c|c|c|c|c|}
\hline & AZE & GRE & IRE & ITA & POR & BEL & UK \\
\hline $\begin{array}{l}\text { Correlation } \\
\text { Coefficient }\end{array}$ & -0.075 & 0.191 & 0.275 & -0.345 & 0.0191 & -0.303 & -0.149 \\
\hline
\end{tabular}

however, there is not strong correlation between government debt and FDI inflows.

\section{CONCLUDING REMARKS}

The article briefly analyzed the triggering issues of European debt crises. The underlying reason was vulnerabilities of fiscal sustainability. Although, the Euro zone sovereign debt crisis has been caused by several factors, including loss of confidence, contagion effects, structural issues, one of the triggering reason was rising government debts. Taking into account this, in empirical part, I used standard unit root test to detect the fiscal sustainability for selected Euro zone countries, UK including Azerbaijan. Test resulted yield to non-stationary debt-to-GDP ratio in levels, which implicitly indicates nonstationary of debt to GDP ratio. Needless to mention that, in our first difference results we obtained stationary results for all countries, including Azerbaijan. Yet, having in mind some theoretical approach the stationary is not only sufficient condition to analyze for fiscal sustainability, and for further expansion of our research other factors that should be taken into consideration and analyzed.

\section{References:}

1. Afonso, A. Rault, C. (2010), Long-Run Determinants of Sovereign Yields, CESifo Working Paper Series No. 3155

2. Bravo, A. and Silvestre, A. L. (2000), Fiscal Sustainability, Electoral Cycles and The European Constraint" Instituto Superior de Economia, Technical University of Lisbon papers. pp. 17-18.

3. Bohn, H. (2007), "Are Stationarity and Cointegration Restrictions Really Necessary for thevlntertemporal Budget Constraint?", Journal of Monetary Economics 54, pp. $1837-1847$.

4. BBC News, (2011). Eurozone: France and Germany call for tougher treaty. BBC News, [online] 5 December. Available at: <http://www.bbc.co.uk/news/worldeurope-16037425

5. B.Eduard, T.Vyrost \& Stefan Lyocsa, (2011) "Are we able to capture the EU debt Crisis? Munich Personal RepEc Archive (MPRA) paper No.30334 pp. 4-5

6. Piergallini.A and Postigliola M, (2011). "Fiscal Policy and Public Debt Dynamics in Italy", 1861-2009 University of Rome "Tor Vergata" database; pp. 10-11.

7. Pilbeam, K. (2006). International finance. 3rd ed. Houndmills, UK: Palgrave Macmillan

8. Smith, A. (2011), French bank downgrade is latest blow to Europe CNN Money: <http://money.cnn.com/ $2011 / 09 / 14 /$ news/xxxinternational/moodys_french banks/index.htm $>$

9. World bank Indicators, (2016). "Economy and Growth" https://data.worldbank.org/indicator

10. Polito, V. and Wickens, M. (2011). "Measuring the Fiscal Stance in the United States and the European Union, 1970-2011" European Economic Review, pp. 30-31. Стаття надійшла до редакиії 04.04.2019 p. 